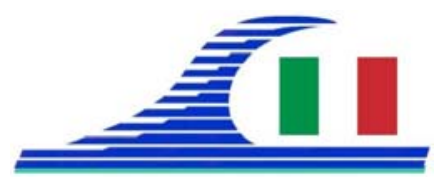

Conférence Méditerranéenne Côtière et Maritime EDITION 3, FERRARA, ITALIA (2015)

Coastal and Maritime Mediterranean Conference

Disponible en ligne - http://www.paralia.fr - Available online

\title{
The role of particle shape on pebble transport in a mixed sand and gravel beach (Portonovo, Italy)
}

\section{Edoardo GROTTOLI ${ }^{\mathbf{1}}$, Duccio BERTONI ${ }^{\mathbf{1}}$, Paolo CIAVOLA ${ }^{\mathbf{1}}$, Alessandro POZZEBON ${ }^{4}$}

\author{
1. Università di Ferrara, Dipartimento di Fisica e Scienze della Terra, Via Giuseppe \\ Saragat 1, 44122 Ferrara, Italy. \\ grtdrd@unife.it \\ 2. Università di Siena, Dipartimento di Ingegneria dell'Informazione e Scienze \\ Matematiche, Via Roma 56, 53100 Siena, Italy.
}

\begin{abstract}
:
A better knowledge of the relationship between sediment characteristics and sediment transport is crucial to establish the suitability of fill material for gravel nourishments. In this paper pebble transport is investigated by means of RFID passive tracing technology. Tracers were injected in a small portion of a mixed sand and gravel beach separating sphere from disc shaped pebbles. Tracer recovery was undertaken 6 and $24 \mathrm{~h}$ after the injection and wave characteristics were measured during the whole experiment duration. After $6 \mathrm{~h}$ the marked pebbles already covered significant displacements with a prevalent longshore component which became evident after $24 \mathrm{~h}$. According to statistical analyses (T-tests and box plots) no significant difference among the displacement of different shapes resulted. The swash zone proved to be the most dynamic area of the beach where all the pebble displacements took place. Because of their higher dynamic, spheres are preferred to discs for nourishment purposes.
\end{abstract}

Keywords: Sediment transport, RFID tracer, Mixed beach, Pebble, Swash, Gravel nourishment, Particle shape, Microtidal beach, Tracers.

\section{Study area}

Portonovo is located at the northern edge of the Conero Headland in the central sector of the Adriatic Sea (see Figure 1). The beach is located on the eastern side of the village; it is approximately $500 \mathrm{~m}$ long and $20-60 \mathrm{~m}$ wide and is bounded by two boulder seawalls protecting historical buildings. According to the JENNINGS \& SHULMEISTER (2002) classification, Portonovo is a mixed sand and gravel beach (MSG) and gravel is the prevalent fraction mainly formed by pebbles. Sediments are made of limestone and marl originated by cliff erosion which is the only sediment source of the beach. The beach face typically slopes 0.2 , whereas the seabed off the step is approximately 0.01 . The beach looks highly heterogeneous: sand and scattered gravel accumulations cover the backshore whereas the gravel fraction usually occupies the swash zone, with granules and fine pebbles normally found on the berm and in the 
Côtes méditerranéennes menacées :

Risques et défis dans le contexte du changement climatique

swash zone while cobbles and boulders usually build the step. The average tidal range at spring tide is $40 \mathrm{~cm}$. The dominant winds come from the NE and SE, which correspond also to the directions of the main storms. The wave heights are between 0.25 and $2 \mathrm{~m}$ in the majority of occurrences, with $20 \%$ of waves coming from SE and $15 \%$ from NE. Between 2006 and 2011, gravel replenishments made of alluvial material were carried out by local authorities: a total amount of $18500 \mathrm{~m}^{3}$ of pebbles and cobbles $(4-100 \mathrm{~mm}$ in diameter) of limestone was unloaded, mostly on the western side of Portonovo (see Figure 1). The exact location and quantity of fill material released in the eastern side of the town, where the study site is located, are unknown.

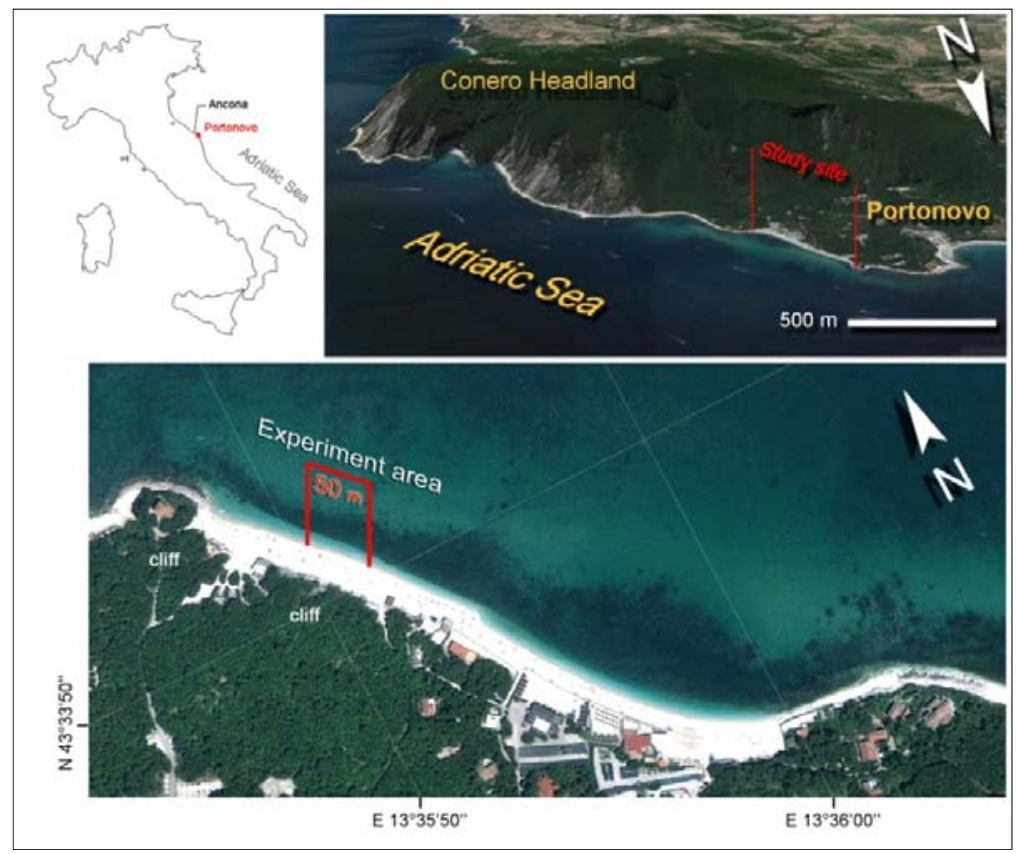

Figure 1. Study site.

\section{Materials and methods}

\subsection{RFID technique and tracer displacement}

The tracer displacement was investigated by means of RFID technology. The technology is composed of two devices: an RFID radio signal antenna (or RFID reader) and a transponder (or tag). The tag is provided by an alphanumeric code which is the element allowing the unequivocal identification of the pebble to which is coupled. Once a tracer is detected, a message appears on the laptop which is connected to the reader, an acoustic signal is also emitted by the antenna as an additional warning sign of pebble detection. The reader generates a sphere shaped electro-magnetic field with a $40 \mathrm{~cm}$ radius, which represents the maximum detection range both underwater and in subaerial environments. The marked pebbles were prepared by drilling a hole along the longer 
axis in order to accommodate the tag; the hole was sealed with a waterproof resin, reducing the original weight by no more than $3 \mathrm{~g}$. The smallest size that can be drilled with the kind of tag we used is up to -4.5 phi. Pebbles were randomly collected from the beach surface (backshore and beach face), then were divided in spheres and discs of the similar size. The pebble displacements were measured by means of an RTK-DGPS (Trimble R6, instrument accuracy approximately $\pm 2 \mathrm{~cm}$ ). Tracer displacement was also investigated by means of statistical analyses (T-tests and box plots). Box plots are another way to represent Gaussian distribution of something (in this case pebble displacement). T-tests are statistical analyses that say if differences in a certain measurement between two groups (in this case pebble displacement among spheres and discs) is relevant or not under a certain confidence level (in this case 95\%).

\subsection{Experiment set up}

The experiment area was set up on a straight portion on the northern part of the beach (see Figure 1) to avoid the influence of non-linear shoreline and longshore protections which could alter pebble displacements as experienced in previous works (BERTONI et al., 2013, GROTTOLI et al., 2015). At 10:00 am of May 20 ${ }^{\text {th }} 2014,60$ marked pebbles (30 spheres and 30 discs) were injected on 10 cross-shore profiles $5 \mathrm{~m}$ spaced which covered an area $50 \mathrm{~m}$ long. All the tracers had approximately the same characteristics (weight min. 70 g, max. 188 g; size min. -5.3 phi, max. -5.9 phi). Tracers were injected on the beachface of each profile as follows: 2 tracers ( 1 sphere and 1 disc) on the fairweather berm; 2 tracers ( 1 sphere and 1 disc) at swash mid-point and 2 tracers ( 1 sphere and 1 disc) on the beach step. Tracers were coupled trying to avoid large difference in size and weight. During the experiment, the wave characteristics were recorded by means of an InterOcean S4 directional wave gauge. The device was deployed on the bed seaward of the beachface ( $-1.5 \mathrm{~m}$ below the Mean Sea Level) to keep it underwater for the entire acquisition time. Two time series of 20 min per each hour with a separation of 10 min were provided, measuring the water level and wave parameters at a frequency of $2 \mathrm{~Hz}$. The device was operative throughout the entire experiment duration and has an accuracy of $0.004 \mathrm{~m}$.

\section{Results}

Low energy conditions were recorded during the experiment with an average significant wave height of $0.1 \mathrm{~m}$ (max value $0.23 \mathrm{~m}$ ) and a peak wave period of $6 \mathrm{~s}$. The wave direction was dominant from E. Tracer recovery after $6 \mathrm{~h}$ was 85\%, (87\% of spheres, $83 \%$ among discs) which decreased to $52 \%$ after 24 h (53\% between spheres, $50 \%$ of discs). Most of the tracers moved more than $0.5 \mathrm{~m}$ (60\% of the whole) after the first recovery, with a maximum displacement of $19.4 \mathrm{~m}$. After $24 \mathrm{~h}, 30 \%$ of the recovered tracers moved more than $0.5 \mathrm{~m}$ and the maximum measured displacement was $35.2 \mathrm{~m}$. Considering the shape of pebbles, $60 \%$ of spheres and discs moved more than $0.5 \mathrm{~m} 6 \mathrm{~h}$ 
Côtes méditerranéennes menacées :

Risques et défis dans le contexte du changement climatique

after the injection. After one day 30\% of the tracer was recovered for each shape $30 \%$ of spheres and $30 \%$ of discs). The prevalent displacement was longshore both for disc and sphere shaped pebbles. After $6 \mathrm{~h}$, most of the tracers moved on the beach face, with the stronger longshore component that affected the tracers injected in the southern part of the experiment area (see Figure 2). Some tracers moved from the berm to the step whereas some others travelled backwards. Such a trend affected each shape because no differences in the displacement direction related to pebble shape were noted. One day after the injection the longshore component became clearer and no cross-shore displacement were detected.

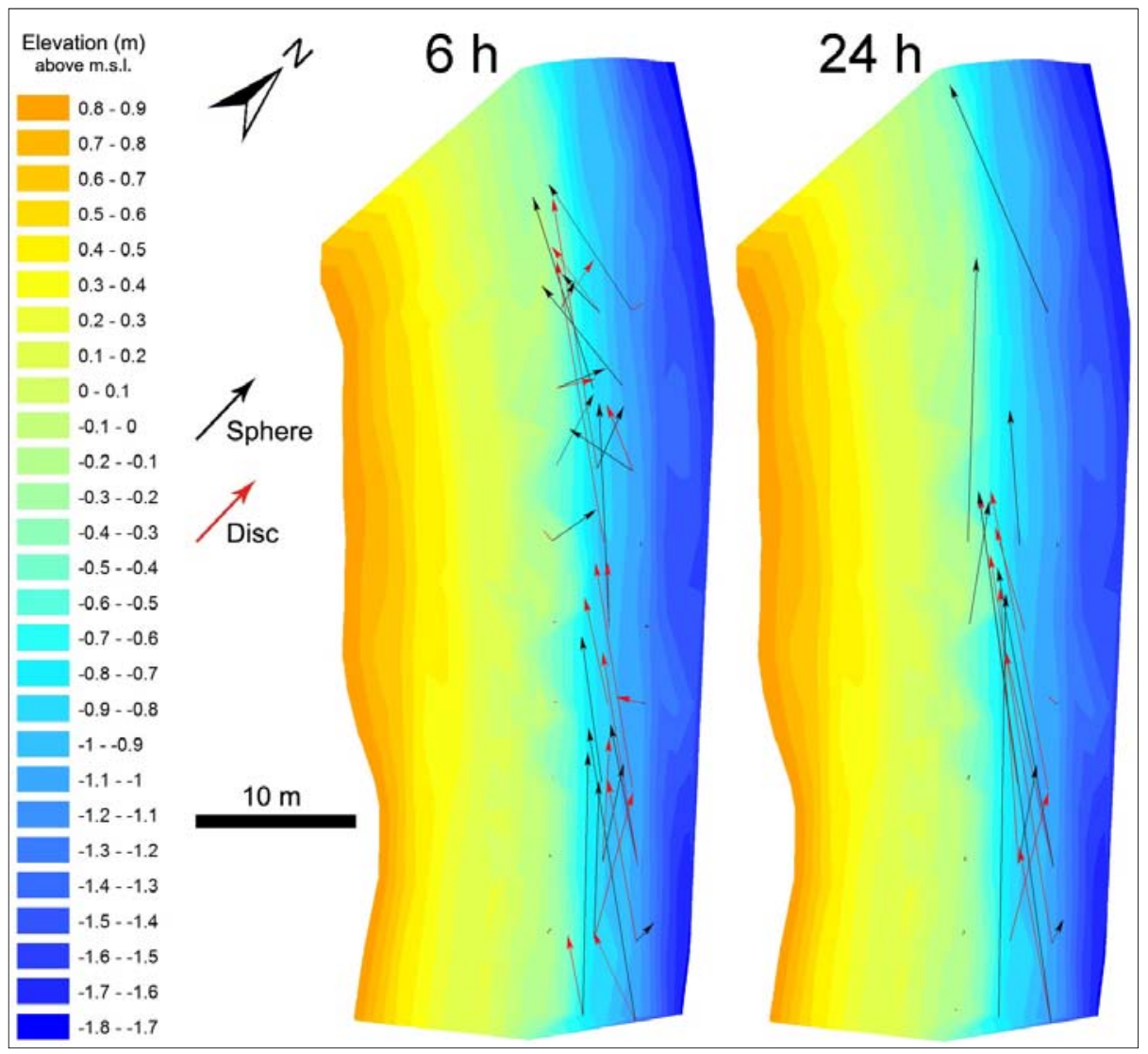

Figure 2. Displacement map 6 and $24 \mathrm{~h}$ after the tracer injection according to tracer shape.

All the size box plots related to tracer displacement are skewed towards spheres (see Figure 3). After $6 \mathrm{~h}$ the distributions of both shapes are quite similar: the median displacement is $5 \mathrm{~m}$ and the interquartile range is within $10 \mathrm{~m} .24 \mathrm{~h}$ after the injection sphere shaped pebbles reached larger distances compared to discs even though the median value of discs is greater. One day after the injection the interquartile range is basically the same (up to 16-17 m) but the longest distances were covered by spheres. 
According to T-tests there is no statistical difference based on shape among the displacements of spheres and discs.

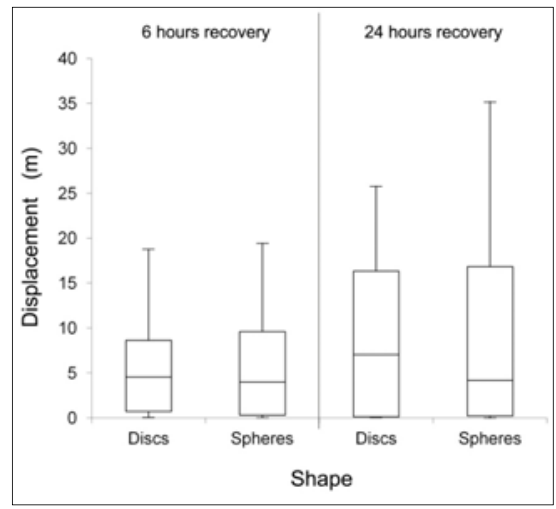

Figure 3. Box plots showing tracer displacements according to shape.

\section{Conclusions}

This study presents an original contribution to the understanding of the role of pebble shape on controlling sediment transport. Spheres seem more dynamic than discs. Under low to moderate wave conditions all shapes move in the swash zone with a predominant longshore component and non-marginal displacements. However, from this experiment emerged that there is no statistical relationship between the shape of the pebbles and their displacements. Other experiments done in Portonovo these years showed that a role of pebble shape is not negligible: according to GROTTOLI et al. (2015) discs can cover longer distances but are less dynamics than spheres on the whole. Actual measurements of swash velocities, which are able to initiate pebble migration, should be obtained to improve threshold velocity formulas, which currently do not include any shape parameter. Shape can be a discriminant factor for pebble transportation, at least under low energy condition. Since artificial replenishments made with gravelly material have become more popular in recent years, studies dealing with particle shape or other characteristics have important implications. For nourishment purposes a spherical shape should be preferred being spheres more dynamic than discs and tending to avoid the formation of permanent areas in erosion or in strong accumulation on the beach.

\section{References}

BERTONI D., GROTTOLI E., CIAVOLA P., SARTI G., BENELLI G., POZZEBON A. (2013). On the displacement of marked pebbles on two coarse-clastic beaches during short fair-weather periods (Marina di Pisa and Portonovo, Italy). GeoMarine Letters, Vol. 33, pp 463-476. http://dx.doi.org/10.1007/s00367-013-0341-3 
Côtes méditerranéennes menacées :

Risques et défis dans le contexte du changement climatique

GROTTOLI E., BERTONI D., CIAVOLA P., POZZEBON A. (2015). Short term displacements of marked pebbles in the swash zone: focus on particle shape and size. Marine Geology, Vol. 367, pp 143-158. http://dx.doi.org/10.1016/j.margeo.2015.06.006

JENNINGS R., SHULMEISTER J. (2002). A field based classification scheme for gravel beaches. Marine Geology, Vol. 186, pp 211-228. http://dx.doi.org/10.1016/S0025$\underline{3227(02) 00314-6}$ 